Williamson, G. M. (1958). J. gen. Microbiol. 19, 584-591

\title{
Dihydrostreptomycin and Anaerobiosis-Indirect Evidence for Two Sites of Action of Dihydrostreptomycin
}

\author{
By G. M. WILLIAMSON \\ Department of Bacteriology, The School of Medicine, Leeds
}

SUMMARY: The sensitivity of 4 strains of Escherichia coli and of Aerobacter aerogenes when growing under aerobic and under anaerobic conditions in heavily buffered enriched medium was compared. Each comparison covered a series of $\mathrm{pH}$ values from 5.5 to 8.0. A distinct pattern emerged for each group of organisms and this would appear to be related to the enzymic make-up of the organism with respect to carbohydrate metabolism and not to the $\mathrm{pH}$ developed in the medium during growth or to the growth rate of the organism. Comparison of the behaviour of $A$. aerogenes under identical conditions, but in a simple medium, suggests that dihydrostreptomycin is more effective against synthesizing than against energy-producing mechanisms.

The activity of streptomycin and dihydrostreptomycin is decreased under anaerobic conditions (Bondi, Dietz \& Spaulding, 1946; Geiger, Green \& Waksman, 1946; Hurowitz, Rosano, Blattberg \& Rosenfeld, 1955; Williamson \& White, 1956). Three suggestions have been advanced to explain this phenomenon. First, an altered environment, the direct effect of the incomplete catabolism of metabolites. This gives rise to acidic end-products, lowering the $\mathrm{pH}$ of the medium and thereby decreasing the effective concentration of the antibiotic (Geiger et al. 1946). Secondly, a slower rate of growth, for it has been stated that the faster an organism grows the greater its sensitivity; indeed there would appear to be a direct relationship (Hurowitz et al. 1955). Finally, 'the antibacterial action of streptomycin may be due to its ability to block some enzyme system, oxidative in nature, which is essential only to the growth of susceptible aerobic bacteria, an enzyme system which anaerobes do not possess ' (Bondi et al. 1946). This idea could conceivably apply to facultative anaerobes if their functional enzymic pattern varies with the oxygen content of their environment. Of the many metabolic pathways that may be affected by streptomycin those concerned with carbohydrate breakdown have been most fully investigated. Interference with the aerobic metabolism of pyruvate by Escherichia coli was reported by Oginsky, Smith \& Umbreit (1949) and that of anaerobic dissimilation by Barkulis (1953).|The several pathways for the breakdown of pyruvate by $E$. coli and Aerobacter aerogenes are the same with the exception of that leading to the formation of acetylmethylcarbinol by $A$. aerogenes. Furthermore, this mechanism functions under both aerobic and anaerobic conditions. It was thought that by working under carefully controlled environmental conditions with organisms whose growth rate and general metabolic behaviour was known, some reason for the greater resistance to dihydrostreptomycin of a facultative anaerobe when growing anaerobically might be forthcoming. 


\section{METHODS}

Organisms. Four strains each of Escherichia coli and of Aerobacter aerogenes were used, with the exception of $E$. coli NCTC 5928 and $A$. aerogenes NCTC 418, isolated from routine specimens of faeces.

Media. Two fluid media were used throughout.

(a) Enriched medium: glucose peptone $\mathrm{M} / 6$-phosphate which was made up from four component solutions: (i) Difco proteose peptone, $3.0 \mathrm{~g}$.; $\mathbf{K H}_{2} \mathbf{P O}_{4}$ (Analar), 22.65 g.; distilled water to $950 \mathrm{ml}$. (ii) Difco proteose peptone, 3.0 g.; $\mathrm{Na}_{2} \mathrm{HPO}_{4}$ (Analar), $23 \cdot 65$ g.; distilled water to $950 \mathrm{ml}$. (iii) glucose (Analar), 24 g.; distilled water to $500 \mathrm{ml}$. (iv) $\mathrm{MgSO}_{4} .7 \mathrm{H}_{2} \mathrm{O}, 4.0 \mathrm{~g}$.; $\mathrm{MnSO}_{4} \cdot 4 \mathrm{H}_{2} \mathrm{O}, 2 \cdot 5 \mathrm{~g}$.; distilled water to $100 \mathrm{ml}$.

(b) Chemically defined medium: salt glucose $\mathrm{m} / 6$-phosphate. This was likewise made up from four component solutions: (i) $\mathrm{NH}_{4} \mathrm{Cl}$ (Analar), 4.0 g.; $\mathrm{KH}_{2} \mathrm{PO}_{4}$ (Analar), 22.65 g.; distilled water to $950 \mathrm{ml}$. (ii) $\mathrm{NH}_{4} \mathrm{Cl}$ (Analar), $4.0 \mathrm{~g}$.; $\mathrm{Na}_{2} \mathrm{HPO}_{4}$ (Analar), $23.65 \mathrm{~g}$., distilled water to $950 \mathrm{ml}$., and solutions (iii) and (iv) as above.

From each pair of phosphate solutions a series of mixtures covering the $\mathrm{pH}$ range 5.5-8.0 were prepared and these, together with the sulphate solution, were sterilized by autoclaving at $5 \mathrm{lb}$./sq.in. for $\frac{1}{2} \mathrm{hr}$. The glucose solution was sterilized by filtration.

Both final media eonsisted of $19 \mathrm{ml}$. phosphate mixture; $1.0 \mathrm{ml}$. glucose solution and $0 \cdot 1 \mathrm{ml}$. sulphate solution (iv). After sterilization the $\mathrm{pH}$ value of each series of complete medium was determined on a Cambridge $\mathrm{pH}$ meter.

Dihydrostreptomycin. Crystalline dihydrostreptomycin sulphate (Glaxo) containing $1.0 \mathrm{~g}$. equivalent of the base was dissolved in $10 \mathrm{ml}$. sterile distilled water to give a solution containing $100,000 \mu \mathrm{g}$. equivalents dihydrostreptomycin $/ \mathrm{ml}$. This was then used to prepare serial dilutions of the antibiotic. These dilutions, ranging from 1024 to $0 \cdot 25 \mu \mathrm{g}$. equivalents dihydrostreptomycin/ml., were made up in the series of phosphate mixtures; a clean drysterilized pipette was used for each manipulation, so that any error due to 'carry-over' of fluid adhering to the outside of the pipette was eliminated. Such stock solutions, if not used immediately, were stored at $4^{\circ}$. Under such conditions of storage their potency, as assayed against Klebsiella pneumoniae, strain 41, remained constant for at least 1 month. No stock solutions kept for longer than 3 weeks were deemed suitable for accurate work.

Anaerobiosis. The anaerobic experiments were carried out in a MacIntosh and Fildes' anaerobic jar refilled, after evacuation, with hydrogen. To ensure a satisfactory anaerobic atmosphere the jar was evacuated and refilled with hydrogen three times. Reduced alkaline methylene blue was used as indicator of anaerobic conditions. When the number of tubes in an experiment necessitated the use of more than one jar, the jars were connected in series for evacuation and refilling.

Cleaning of glass-ware. All glass-ware was carefully cleaned by boiling in $10 \%$ nitric acid followed by washing with glass-distilled water. 


\section{Determination of sensitivity to dihydrostreptomycin}

Before each experiment the organism to be tested was first examined for purity and characteristic biochemical behaviour. It was then grown, by serial subculture on 3 successive days, in the medium and under the atmospheric conditions in which it was to be tested. A separate culture was prepared for each $\mathrm{pH}$ at which observations were to be made so that the enzymic constitution of the inoculum would be established and fixed. The last of the serial cultures was suitably diluted to give an inoculum yielding consistent growth in the controls (usually in the case of the glucose peptone medium 1/1000 and of the salt glucose medium 1/100).

Before determining the sensitivity to dihydrostreptomycin of the organism under examination growing aerobically and anaerobically a pilot aerobic experiment was set up to obtain an approximate estimate of its sensitivity throughout the $\mathrm{pH}$ range under consideration.

A range of doubling dilutions of dihydrostreptomycin straddling the sensitivity level obtained in the pilot experiment was then used for each $\mathrm{pH}$ value at which the organism was to be tested. $0.5 \mathrm{ml}$. samples of each dilution were then inoculated with $0.05 \mathrm{ml}$. of diluted culture. Groups of triplicate tubes were incubated aerobically and anaerobically in parallel. The results were read after $16 \mathrm{hr}$. incubation and then daily for 5 days. This was to enable any highly resistant cells in the inoculum to make themselves evident. In no case was the reading at 5 days greater than that after $16 \mathrm{hr}$. incubation. In other words the inoculum was uniform with respect to the degree of resistance to dihydrostreptomycin. For each $\mathrm{pH}$ a growth control, without dihydrostreptomycin, was included. In every experiment the density of growth was always greater under aerobic than under anaerobic conditions. Furthermore, oxygen did not appear to be a limiting factor in the aerobic experiments as aeration following the $16 \mathrm{hr}$. reading did not affect the result. After incubation each tube was subcultured on to nutrient agar to verify that turbidity was due to growth and to ensure purity of the culture.

\section{Determination of rate of growth}

Growth rate studies were made on Escherichia coli NCTC 5928 growing in peptone-glucose and on Aerobacter aerogenes, faecal strain $\mathbf{R}$, growing in both media. Each organism was examined at $\mathrm{pH} 5.5,6.5$ and 7.5 when growing aerobically and anaerobically. The growth at $\mathrm{pH} 5 \cdot 5$ was too irregular to give consistent results as between replicates.

The aerobic studies were carried out in $50 \mathrm{ml}$. Erlenmeyer flasks containing a depth of medium equivalent to that in the aerobic culture tubes of the sensitivity experiments. The culture was transferred for turbidometric reading to a sterile $6 \times \frac{5}{8}$ in. test tube. Despite repeated disturbance in this manner a smooth growth curve was obtained suggesting adequate aeration. This belief was substantiated not only by a greater final density of growth than that reached in the parallel anaerobic cultures, but also by the failure of more vigorous aeration to stimulate further growth. 
The anaerobic studies were made in specially adapted $6 \times \frac{5}{8}$ in. Pyrex test tubes which were evacuated, filled with hydrogen and clipped off. A nutrient broth contained in a similar tube and inoculated with the anaerobe Clostridium welchii was evacuated, filled with hydrogen and incubated in parallel as an indicator of anaerobic conditions. Direct turbidometric readings could thus be made on a culture growing anaerobically.

Each study, in parallel under aerobic and anaerobic conditions, was done in triplicate on three separate occasions.

\section{RESULTS}

The sensitivity to dihydrostreptomycin of the test organisms growing in glucose-peptone $\mathrm{M} / 6-$ phosphate

The sensitivity to dihydrostreptomycin of the 4 strains of Escherichia coli and Aerobacter aerogenes growing under aerobic and anaerobic conditions is recorded in Table 1. One strain of each organism, $E$. coli NCTC 5928 and $A$. aerogenes $\mathbf{R}$, was examined in greater detail.

From this survey it is seen that over a wide $\mathrm{pH}$ range the bactericidal activity of dihydrostreptomycin towards Escherichia coli is twice as great under aerobic as under anaerobic conditions. With Aerobacter aerogenes this greater activity is displayed only above $\mathrm{pH} 7 \cdot \mathbf{0}$.

The sensitivity to dihydrostreptomycin of Aerobacter aerogenes $\mathbf{R}$ growing in salt-glucose $\mathrm{M} / 6-$ phosphate

The constituents of the medium in which the sensitivity of an organism to dihydrostreptomycin is determined may influence the result (Williamson, 1957). An examination of the same organisms growing in a simpler medium under otherwise identical conditions was next attempted. Comparison with the richer medium, however, was possible only with Aerobacter aerogenes $\mathbf{R}$ for this was the only organism found out of many examined which gave consistent growth under strictly anaerobic conditions at each $\mathrm{pH}$ used. In Table 2 the results obtained are compared with those using the glucosepeptone medium. The general pattern is the same in both media, although it will be noted that the test organism is at least four times as sensitive to dihydrostreptomycin when growing in the simpler medium. This result is in keeping with previous reports on the inhibitory effect of peptones (Lenert \& Hobby, 1947; Foster \& Pittillo, 1953). More important, the sensitivity of the organism is the same under aerobic and under anaerobic conditions.

The rate of growth of Escherichia coli NCTC 5928 and of Aerobacter aerogenes $\mathbf{R}$

Hurowitz et al. (1955) reported that the sensitivity of Escherichia coli B to dihydrostreptomycin multiplied by the reciprocal of rate of growth was a constant $(k)$. If this is so then the results obtained in glucose-peptone might be explained on this basis. However, a study of Table 3 shows that the value of $k$ is not the same within those pairs showing a difference in sensitivity. As 
might be expected the mean generation time of Aerobacter aerogenes $\mathbf{R}$ in the salt-glucose medium was slower $(72 \mathrm{~min}$.) than in the enriched medium and thus unrelated to the greater sensitivity to dihydrostreptomycin of this organism when growing in the simpler medium.

Table 1. Sensitivity to dihydrostreptomycin of a number of strains of Aerobacter aerogenes and of Escherichia coli grown under aerobic and anaerobic conditions over a wide $\mathrm{pH}$ range in glucose peptone $\mathrm{m} / 6-$ phosphate

Concentration of dihydrostreptomycin $\mu \mathrm{g} . / \mathrm{ml}$. inhibiting growth of

\begin{tabular}{|c|c|c|c|c|c|c|c|c|c|}
\hline \multirow[b]{2}{*}{ pH } & \multirow[b]{2}{*}{$\begin{array}{l}\text { Conditions } \\
\text { of growth }\end{array}$} & \multicolumn{4}{|c|}{ A. aerogenes } & \multicolumn{4}{|c|}{ E. coli } \\
\hline & & $\mathbf{R}$ & $\begin{array}{c}\text { NCTC } \\
418\end{array}$ & 718 & 852 & $\begin{array}{l}\text { NCTC } \\
5928\end{array}$ & 116 & 98 & 82 \\
\hline $5 \cdot 45$ & $\begin{array}{l}\text { Aerobic } \\
\text { Anaerobic }\end{array}$ & $\begin{array}{l}256 \\
128\end{array}$ & $\begin{array}{l}128 \\
128\end{array}$ & $\begin{array}{l}256 \\
128\end{array}$ & $\begin{array}{l}128 \\
128\end{array}$ & $\begin{array}{l}512 \\
256\end{array}$ & $\begin{array}{l}256 \\
128\end{array}$ & $\begin{array}{l}512 \\
512\end{array}$ & $\begin{array}{l}512 \\
512\end{array}$ \\
\hline $5 \cdot 76$ & $\begin{array}{l}\text { Aerobic } \\
\text { Anaerobic }\end{array}$ & $\begin{array}{l}128 \\
128\end{array}$ & - & - & - & $\begin{array}{l}256 \\
256\end{array}$ & - & - & - \\
\hline $5 \cdot 95$ & $\begin{array}{l}\text { Aerobic } \\
\text { Anaerobic }\end{array}$ & $\begin{array}{l}64 \\
64\end{array}$ & $\begin{array}{l}64 \\
64\end{array}$ & $\begin{array}{l}64 \\
64\end{array}$ & $\begin{array}{l}64 \\
64\end{array}$ & $\begin{array}{l}128 \\
256\end{array}$ & $\begin{array}{l}128 \\
128\end{array}$ & $\begin{array}{l}256 \\
256\end{array}$ & $\begin{array}{l}256 \\
256\end{array}$ \\
\hline $6 \cdot 30$ & $\begin{array}{l}\text { Aerobic } \\
\text { Anaerobic }\end{array}$ & $\begin{array}{l}64 \\
64\end{array}$ & - & - & - & $\begin{array}{r}64 \\
128\end{array}$ & - & - & - \\
\hline $6 \cdot 44$ & $\begin{array}{l}\text { Aerobic } \\
\text { Anaerobic }\end{array}$ & $\begin{array}{l}64 \\
64\end{array}$ & $\begin{array}{l}64 \\
64\end{array}$ & $\begin{array}{l}64 \\
64\end{array}$ & $\begin{array}{l}64 \\
64\end{array}$ & $\begin{array}{r}64 \\
128\end{array}$ & $\begin{array}{r}64 \\
128\end{array}$ & $\begin{array}{l}128 \\
256\end{array}$ & $\begin{array}{l}128 \\
256\end{array}$ \\
\hline $6 \cdot 68$ & $\begin{array}{l}\text { Aerobic } \\
\text { Anaerobic }\end{array}$ & $\begin{array}{l}64 \\
64\end{array}$ & - & - & - & $\begin{array}{l}32 \\
64\end{array}$ & - & - & - \\
\hline 6.95 & $\begin{array}{l}\text { Aerobic } \\
\text { Anaerobic }\end{array}$ & $\begin{array}{l}64 \\
64\end{array}$ & $\begin{array}{l}64 \\
64\end{array}$ & $\begin{array}{l}64 \\
64\end{array}$ & $\begin{array}{l}64 \\
64\end{array}$ & $\begin{array}{l}32 \\
64\end{array}$ & $\begin{array}{l}32 \\
64\end{array}$ & $\begin{array}{r}64 \\
128\end{array}$ & $\begin{array}{r}64 \\
128\end{array}$ \\
\hline $7 \cdot 26$ & $\begin{array}{l}\text { Aerobic } \\
\text { Anaerobic }\end{array}$ & $\begin{array}{l}32 \\
64\end{array}$ & - & - & - & $\begin{array}{l}16 \\
32\end{array}$ & - & - & - \\
\hline $7 \cdot 52$ & $\begin{array}{l}\text { Aerobic } \\
\text { Anaerobic }\end{array}$ & $\begin{array}{l}16 \\
32\end{array}$ & $\begin{array}{l}16 \\
32\end{array}$ & $\begin{array}{l}16 \\
32\end{array}$ & $\begin{array}{l}32 \\
64\end{array}$ & $\begin{array}{l}16 \\
32\end{array}$ & $\begin{array}{l}16 \\
32\end{array}$ & $\begin{array}{l}32 \\
64\end{array}$ & $\begin{array}{l}32 \\
64\end{array}$ \\
\hline $7 \cdot 86$ & $\begin{array}{l}\text { Aerobic } \\
\text { Anaerobic }\end{array}$ & $\begin{array}{r}8 \\
16\end{array}$ & - & - & - & $\begin{array}{r}8 \\
16\end{array}$ & - & - & - \\
\hline $8 \cdot 08$ & $\begin{array}{l}\text { Aerobic } \\
\text { Anaerobic }\end{array}$ & $\begin{array}{l}4 \\
8\end{array}$ & $\begin{array}{r}8 \\
16\end{array}$ & $\begin{array}{r}8 \\
16\end{array}$ & $\begin{array}{l}16 \\
32\end{array}$ & $\begin{array}{l}4 \\
8\end{array}$ & $\begin{array}{r}8 \\
16\end{array}$ & $\begin{array}{l}16 \\
32\end{array}$ & $\begin{array}{l}16 \\
32\end{array}$ \\
\hline
\end{tabular}

Each figure is the average of the results of at least three experiments carried out in triplicate.

Table 2. Concentration of dihydrostreptomycin ( $\mu \mathrm{g} . / \mathrm{ml}$.) inhibiting the growth of Aerobacter aerogenes $\mathbf{R}$ under aerobic and under anaerobic conditions over a wide $p H$ range

\begin{tabular}{clrrrrrrrrrrrr}
\multicolumn{10}{c|}{$\mathrm{pH}$} \\
Medium & $\begin{array}{l}\text { Conditions } \\
\text { of growth }\end{array}$ & $\overbrace{5 \cdot 45}$ & $5 \cdot 76$ & $5 \cdot 95$ & $6 \cdot 30$ & $6 \cdot 44$ & $6 \cdot 68$ & $6 \cdot 95$ & $7 \cdot 26$ & $7 \cdot 52$ & $7 \cdot 86$ \\
ucose peptone & Aerobic & 256 & 128 & 64 & 64 & 64 & 64 & 64 & 32 & 16 & 8 \\
6-phosphate & Anaerobic & 128 & 128 & 64 & 64 & 64 & 64 & 64 & 64 & 32 & 16 \\
lt glucose & Aerobic & 128 & 64 & 32 & 32 & 16 & 16 & 8 & 4 & 2 & 1 \\
6-phosphate & Anaerobic & 16 & 16 & 16 & 16 & 16 & 16 & 8 & 4 & 2 & 1
\end{tabular}

Each figure is the average of the results of at least three experiments carried out in triplicate. 
Table 3. Relationship of mean generation time $(m)$ to sensitivity to dihydrostreptomycin $(s)$ of Aerobacter aerogenes $\mathrm{R}$ and of Escherichia coli NCTC 5928 growing under aerobic and under anaerobic conditions in glucose-peptone $\mathrm{M} / 6$-phosphate

\begin{tabular}{|c|c|c|c|c|c|c|c|}
\hline \multirow[b]{2}{*}{ Organism } & \multirow[b]{2}{*}{$\begin{array}{l}\text { Conditions } \\
\text { of growth }\end{array}$} & \multicolumn{3}{|c|}{ pH 6.5 } & \multicolumn{3}{|c|}{ pH 7.5 } \\
\hline & & $\begin{array}{c}\text { M.G.T. } \\
(\operatorname{min.})=m\end{array}$ & $\begin{array}{l}\text { Sensitive to } \\
\text { dihydro- } \\
\text { streptomycin } \\
(\mu \mathrm{g} . / \mathrm{ml} .)=s\end{array}$ & $k=s \times 1 / \mathrm{m}$ & $\begin{array}{c}\text { M.G.T. } \\
(\min .)=m\end{array}$ & $\begin{array}{l}\text { Sensitive to } \\
\text { dihydro- } \\
\text { streptomycin } \\
(\mu \mathrm{g} . / \mathrm{ml} .)=s\end{array}$ & $k=\boldsymbol{s} \times \mathbf{1} / \mathbf{m}$ \\
\hline A. aerogenes $\mathbf{R}$ & $\left\{\begin{array}{l}\text { Aerobic } \\
\text { Anaerobic }\end{array}\right.$ & $\begin{array}{l}40 \\
44\end{array}$ & $\begin{array}{l}64 \\
64\end{array}$ & $\begin{array}{l}1 \cdot 60 \\
1 \cdot 45\end{array}$ & $\begin{array}{l}35 \\
37\end{array}$ & $\begin{array}{l}16 \\
32\end{array}$ & $\begin{array}{l}0 \cdot 46 \\
0 \cdot 86\end{array}$ \\
\hline $\begin{array}{l}\text { E. coli } \\
\text { NCTC } 5928\end{array}$ & $\left\{\begin{array}{l}\text { Aerobic } \\
\text { Anaerobic }\end{array}\right.$ & $\begin{array}{l}52 \\
56\end{array}$ & $\begin{array}{r}64 \\
128\end{array}$ & $\begin{array}{l}1 \cdot 23 \\
2 \cdot 29\end{array}$ & $\begin{array}{l}44 \\
46\end{array}$ & $\begin{array}{l}16 \\
32\end{array}$ & $\begin{array}{l}0 \cdot 36 \\
0 \cdot 70\end{array}$ \\
\hline
\end{tabular}

Each figure is the average of the results of at least three experiments carried out in triplicate.

\section{DISCUSSION}

The acidic end-products of anaerobic growth cannot be responsible for the decreased activity of dihydrostreptomycin under the conditions here reported, since the buffering power of the phosphate was sufficient to prevent any alteration in the $\mathrm{pH}$ of the medium as a result of bacterial growth. Neither can it be due to a slower rate of growth of the organism under anaerobic conditions for this was almost the same in either air or hydrogen for both Escherichia coli NCTC 5928 and Aerobacter aerogenes R. These facts leave the assumption of a differentiation of the various metabolic systems of the bacterial cell by dihydrostreptomycin as the only possible explanation.

Before enlarging upon this hypothesis it is necessary to consider whether in the aerobic experiments oxygen could have become a limiting factor. This seems unlikely as aeration following the $16 \mathrm{hr}$. reading did not affect the absolute degree of resistance of the test organisms to dihydrostreptomycin. Furthermore, conditions approaching anaerobosis can only occur following growth. In the sensitivity experiments the bactericidal value of dihydrostreptomycin was measured. Since low concentrations of dihydrostreptomycin were effective, when allowance is made for the adverse effect of the high hydrogen ion (Abraham \& Duthie, 1946) and phosphate ion (Berkman, Henry \& Housewright, 1947) concentration of the media, it seems reasonable to assume that its killing power was exerted upon growing and not upon resting organisms (Garrod, 1948) within the inoculum and therefore before aerobic conditions could be rendered even slightly anaerobic as the result of such growth.

It would appear reasonable to suggest that the action of dihydrostreptomycin upon Aerobacter aerogenes $\mathbf{R}$ when growing in the two media is entirely different. In the simpler medium which demands greater synthesizing activity from the organism, dihydrostreptomycin is both more active than in the richer medium and unaffected by the atmosphere in which growth takes place. This would suggest that the synthesizing activities of an organism are the most sensitive to the action of the drug. Since such activities are unrelated 
to the atmosphere in which growth takes place no difference in sensitivity between the two atmospheres is shown. In the richer medium the need for synthesis is less and the site of action of dihydrostreptomycin might be assumed to be on less sensitive systems such as those yielding the energy necessary for synthesis and assimilation, i.e. those concerned with carbohydrate metabolism. At least three such systems are known to exist amongst the coliaerogenes group of organisms: one dependent upon air (the tricarboxylic acid cycle); one sensitive to or depressed by air (Utter \& Werkman, 1944); the phosphoroclastic split; one independent of air (Silverman \& Werkman, 1941; Stahly \& Werkman, 1942); the acetylmethylcarbinol system. The last is present in $A$. aerogenes only and the upper limit of its activity is $\mathrm{pH} 7 \cdot 2$. This is the very $\mathrm{pH}$ below which any difference in sensitivity to dihydrostreptomycin dependent upon atmospheric conditions disappears. That such disappearance may be related to the functioning of this enzyme system and not to any other is suggested by the continuance of the difference in the case of Escherichia coli, an organism whose carbohydrate metabolism differs only in the absence of this system. If this explanation is acceptable then the greater resistance to dihydrostreptomycin exhibited by $E$. coli above $\mathrm{pH} 6.0$ and $\boldsymbol{A}$. aerogenes above $\mathrm{pH} \mathbf{7 \cdot 2}$ when they are growing anaerobically may well be due to the greater resistance to dihydrostreptomycin of the phosphoroclastic system than that of the aerobic tricarboxylic acid cycle.

The action of dihydrostreptomycin can thus be visualized as being on at least two levels, that interfering with synthesis and that affecting the energyproducing mechanisms. The latter is generally more resistant although the degree of resistance varies with the particular system functioning at the time.

The sensitivity pattern exhibited by Aerobacter aerogenes between pH 6.0 and $7 \cdot 0$ suggests two things. First, that the intracellular $\mathrm{pH}$ may well be constant since, despite increasing acidity of the external environment, the degree of sensitivity to dihydrostreptomycin does not vary. In the parallel experiments with Escherichia coli the level of resistance continues to rise with increasing acidity. This observation supports the view of Gale (1951) that the acetylmethylcarbinol system is a neutralization mechanism. Secondly, the acetylmethylcarbinol system must be either more resistant to dihydrostreptomycin than the other two systems or as resistant as the phosphoroclastic system otherwise a difference between the sensitivity of $A$. aerogenes growing under aerobic and under anaerobic conditions would still exist.

Acknowledgement is due to Professors J. W. McLeod, F.R.S., and C. L. Oakley, F.R.S., for their helpful interest in the work.

\section{REFERENCES}

Aвraham, E. P. \& Duthie, E. S. (1946). Effect of pH of the medium on activity of streptomycin and penicillin and other chemotherapeutic substances. Lancet, i, 455 .

BARKULIS, I. L. (1953). Inhibition of the anaerobic pyruvate metabolism of Escherichia coli by dihydrostreptomycin. J. Bact. 65, 337. 
Berkman, S., Henry, R. J. \& Housewright, R. D. (1947). Studies on streptomycin. I. Factors influencing the activity of streptomycin. J. Bact. 53, 567.

Bondi, A., Dietz, C. C. \& Spaulding, E. H. (1946). Interference with the antibacterial action of streptomycin by reducing agents. Science, 103, 399.

Foster, J. W. \& Pittillo, R. F. (1953). Reversal by complex natural materials of growth inhibition caused by antibiotics. J. Bact. 65, 361 .

Gale, E. F. (1951). The Chemical Activities of Bacteria, 3rd ed., p. 137. London: University Tutorial Press, Ltd.

Garrod, L. P. (1948). The bactericidal action of streptomycin. Brit. med. J. i, 382.

GeIGer, W. B., GreEN, S. R. \& Waksman, S. A. (1946). The inactivation of streptomycin and its practical applications. Proc. Soc. exp. Biol., N.Y. 61, 187.

Hurowitz, C., Rosano, B., Blattberg, B. \& Rosenfeld, J. (1955). The effect of subinhibitory doses of dihydrostreptomycin on culturability of Escherichia coli. Antibiot. \& Chemother. 5, 474.

LENERT, T. F. \& HoBby, G. L. (1947). Observations on the action of streptomycin in vitro (I). Proc. Soc. exp. Biol., N.Y. 65, 235.

OGinsky, E. L., Smith, P. H. \& UMbreit, W. W. (1949). The action of streptomycin. I. The nature of the reaction inhibited. J. Bact. 58, 747.

Silverman, M. \& Werkman, C. H. (1941). The formation of acetylmethylcarbinol from pyruvic acid by a bacterial enzyme preparation. J. biol. Chem. 138, 35.

Stahly, G. L. \& Werkman, C. H. (1942). Origin and relationship of acetylmethylcarbinol to 2:2-butylene glycol in bacterial fermentations. Biochem. J. 36, 575 .

UTter, M. F. \& Werkman, C. H. (1944). Formation and reactions of acetyl phosphate in Escherichia coli. Arch. Biochem. 5, 413.

Williamson, G. M. (1957). The mode of action of streptomycin. J. Pharm., Lond. 9, 483.

Williamson, G. M. \& White, F. (1956). Dihydrostreptomycin and anaerobiosiscomparison with other antibiotics and its selectivity with regard to obligate anaerobes. J. gen. Microbiol. 14, 637. 